\title{
NILAI ESTETIKA \\ DALAM UNGKAPAN ADAT MELAYU RIAU KARYA TENAS EFFENDY SUNTINGAN MAKMUR HENDRIK DAN KAWAN-KAWAN
}

\author{
Muhammad Nassarudin ${ }^{1}$, Sumiharti ${ }^{2}$, Erlina Zahar ${ }^{3}$ \\ Program Studi Pendidikan Bahasa dan Sastra Indonesia, \\ Fakultas Keguruan dan Ilmu Pendidikan, Universitas Batanghari, \\ Jambi \\ Nassarudin01@yahoo.com \\ Harti.sumi@yahoo.com \\ Erlina_zahar@yahoo.co.id
}

\begin{abstract}
This research is aimed at describing the aesthetics values that are found in the expression of Riau Malay Custom by Tenas Effendy in the book Tegak Menjaga Tuah, Duduk Memelihara Marwah edited by Makmur Hendrik and friends. Aesthetics value is the element of beauty in literary work and it is a phenomenon of flowers and smells. The beauty is created byan author with language tools through particular language exploration where the author shows the aspects of beauty optimally. This research is qualitative descriptive by using structural and stylistic. The data is taken from aesthetics values in the expression of Riau Malay by Tenas Effendy in the book Tegak Menjaga Tuah, Duduk Memelihara Marwah edited by Makmur Hendrik and friends. Moreover, the conclusion is made besd on the expressions found in that book. Based on the analysis, it can be concluded that Tegak Menjaga Tuah, Duduk MemeliharaMarwah book edited by Makmur Hendrik and friends comprises 25 expressions of aesthetic values of Riau Malay.
\end{abstract}

Key Words: aesthetic values, Riau Malay expression

\footnotetext{
${ }^{1}$ Mahasiswa Program Studi Pendidikan Bahasa dan Sastra Indonesia, Fakultas Keguruan dan Ilmu Pendidikan, Universitas Batanghari, Jambi

${ }^{2}$ Dosen Program Studi Pendidikan Bahasa dan Sastra Indonesia, Fakultas Keguruan dan Ilmu Pendidikan, Universitas Batanghari, Jambi

${ }^{3}$ Dosen Program Studi Pendidikan Bahasa dan Sastra Indonesia, Fakultas Keguruan dan Ilmu Pendidikan, Universitas Batanghari, Jambi
} 


\section{PENDAHULUAN}

Karya sastra merupakan bentuk dan hasil karya imajinatif dan kreatif yang objeknya manusia dengan menggunakan bahasa sebagai medianya. Menurut Wellek dan Warren (2016: 3) "Karya sastra adalah suatu kegiatan kreatif, sebuah karya seni. Hasil karya sastra tersebut merupakan manifestasi dari imajinasi, hasil berpikir, pengalaman, idealisme, gagasan/pikiran, ataupun bentuk luapan emosi yang sepontan dari pengarang".

Menurut Teeuw (2013: 32) "Karya sastra dipandangan sebagai sesuatu yang otonom, berdiri sendiri, bebas dari pengarang, realitas, maupun pembaca". Menurut Sugono (dalam Damayanti 2013: 12) "Pada dasarnya karya sastra adalah wujud permainan kata-kata pengarang berisikan maksud tertentu yang akan disampaikan kepada penikmat sastra". Selain itu, nilai-nilai yang terkandung dalam karya sastra sangat baik untuk pedoman dalam kehidupan yang disampaikan penulis kepada pembaca salah satunya nilai-nilai estetika yang terkandung dalam karya sastra.

Nilai-nilai estetika merupakan nilai keindahan yang melekat pada karya seni, termasuk karya sastra, menurut (Kosasih 2008: 97) "Keindahan sebuah puisi disebabkan oleh diksi, majas, rima dan irama yang terkandung dalam karya sastra itu".Sehingga pembaca dapat menikmati sebuah karya sastra yang indah dalam bentuk lisan maupun tulisan, begitu juga dalam karya sastra berbentuk ungkapan adat Melayu Riau.

"Ungkapan adat Melayu Riau biasanya berisi tentang ungkapan yang menjunjung tinggi keadilan dan kebenaran, serta mengandung nilai-nilai luhur dalam kehidupan orang Melayu" (Hendrik dkk 2005:50). Pentingnya ungkapan adat Melayu Riau dalam kehidupan masyarakat Melayu yaitu untuk mengatur hampir semua sisi kehidupan, memberikan arahan dan landasan dalam semua kegiatan, mulai dari hal yang besar sampai kepada hal yang kecil.

Ungkapan adat Melayu Riau mengajak orang untuk menjadi manusia beradab, bersopan-santun, toleran, saling menghormati, tahu diri, tolong-menolong agar dapat menciptakan suasana kerukunan dan kedamaian dalam kehidupan bersmasyarakat, berbangsa dan bernegara. Namun, hal tidak sesuai harap yang diingginkan karena dalam kehidupan saat ini masih banyak masyarakat khusunya di Indonesia contoh pada berita yang di ambil peneliti dari Tribun Jambi edisi Sabtu, 03 Maret 2018 "Pemuda Dua Desa Nyaris Bentrok" di Kota Bengkalis J1. Baru, Desa Wonosari Kecamatan Bengkalis, yang mana kurangnya kerukunan dan kedamaian anatara remaja sehingga fungsi dari ungkapan tersebut tidak berjalan sesuai harapan yang diingginkan.

Fokus penelitian ini adalah aspek nilai-nilai estetika gaya bahasa perulangan asonansi pada tiap-tiap bait ungkapan adat Melayu Riau karya Tenas Effendy pada buku Tegak Menjaga Tuah, Duduk Memelihara Marwah suntingan Makmur Hendrik dan kawankawan. Adapun pertanyaan dalam penelitian ini adalah bagaimanakah nilainilai estetika gaya bahasa perulangan asonansi dalam ungkapan adatMelayu Riau karya Tenas Effendy?

Penelitian ini bertujuan untuk mendeskripsikan nilai-nilai estetika gaya bahasa perulangan asonansi yang terdapat dalam ungkapan adat Melayu Riau karya Tenas Effendy pada buku 
Tegak Menjaga Tuah, Duduk Memelihara Marwah suntingan Makmur Hendrik dan kawan-kawan.

"Estetika bukanlah cara untuk menikmati keindahan, akan tetapi usahausaha memahaminya" Menurut Satoto (2012: 8). Kedudukan estetika sangat dominan dalam susastra. Rene Welleck dan Austin Werren (dalam Satoto, 2012: 9) "Bahwa sastra adalah karya imajinasi yang estetikanya dominan, dengan mengunakan bahasa sebagai media atau bahasa bakunya".

Menurut Edraswara (2003: 68) "Keindahan adalah sebuah aplikasi dari intresa dan inscape. Intresa adalah pengaruh yang nyata dari segi Tuhan terhadap cipta kreatif seorang sastrawan, sedangkan inscape adalah pemahaman atau kekuatan melihat sesuatu dengan pikiran dan hati sebagai suatu realitas dalam sastra berdasarkan kebenaran Tuhan".

Menurut Kosasih (2008: 97) "Keindahan sebuah puisi disebabkan oleh diksi, majas, rima dan irama yang terkandung dalam karya sastra itu". Dalam arti teknis, estetika (Aesthetich) berarti ilmu keindahan ilmu mengenal kecantikan secara umum. Estetika bukanlah cara untuk menikmati keindahan, akan tetapi usaha-usaha memahaminya. Estetika berasal dari kata Yunani Aesthesis berarti perasaan atau sensitivitas.Pengertian ini didasarkan atas kenyataan bahwa keindahan memang erat sekali hubungannya dengan lidah dan selera keindahan perasaan dalam bahasa Jerman disebut Geschmack atau dalam bahasa Inggris disebut Teste Menurut Satoto, (2012: 8).

Menurut Pradopo, (2002: 63) "Gaya bahasa adalah sarana sastra yang turut menyumbangkan nilai kepuitisan atau estetik karya sastra, bahkan seringkali nilai seni karya sastra ditentukan oleh gaya bahasanya". Sementara menurut Kosasih (2008: 97) "Bahasa figuratiif (majas) ialah bahasa yang digunakan penyair untuk mengatakan sesuatu dengan cara membandingkan dengan benda atau kata lain".

Menurut Wardoyo (2013: 23) "Bahasa Kiasan (majas) adalah bahasa yang digunakan untuk mendapatkan kepuitisan atau kiasan". Gaya bahasa sebagai cara untuk mengungkapkan pikiran melalui bahasa secara khas. Selanjutnya, menurut Tarigan (2008: 144) "Dengan pengenalan serta pemahaman sejumlah gaya bahasa, kita akan lebih mantap lagi menikmati keindahan karya sastra tersebut". Selanjutnya, menurut Keraf (2009: 113) "Gaya bahasa adalah cara mengungkapkan pikiran melalui bahasa yang khas yang memperhatikan jiwa dan kepribadian penulis (pemakai bahasa) serta mengandung tiga unsur yaitu kejujuran, sopan santun dan menarik". "Gaya bahasa sastra adalah ragam yang digunakan pengarang untuk memperindah teks karya sastra" (Edraswara 2003: 71).

Menurut Tarigan (2009: 134) "Asonansi adalah sejenis gaya bahasa repetisi yang berwujud perulangan vokal yang sama untuk memperoleh efek penekanan atau menyelamatkan keindahan". Selanjutnya, menurut Keraf (2016: 130) "Gaya bahasa asonansi adalah semacam gaya bahasa yang berwujud perulangan bunyi vokal yang sama. Biasanya dipergunakan dalam puisi, kadang-kadang juga dalam prosa untuk memperoleh efek penekanan atau sekedar keindahan"

Beberapa penelitian relevan berikut diambil dari jurnal

1. Penelitian yang ditulis oleh Cyrlius Angga Mundisari, mahasiswa 
Universitas Sebelas Maret Surakarta. Berjudul "Nilai Estetika dan Makna dalam Novel Dom Semurup Ing Banyu karya Suparto Brata: Suatu Tinjauan Struktural Robert Stanton. Penelitian ini dilakukan pada tahun 2011. Tulisan ini relevan dengan penelitian yang dilakukan peneliti karena sama-sama menganalisis nilai estetika dalam buku. Perbedaannya adalah pada objek penelitiannya yakni peneliti sebelumnya pada novel sedangkan peneliti pada buku ungkapan adat Melayu, dan berangkat dari landasan teori ahli yang berbeda sehingga aspek nilai-nilai estetika yang dikaji pun klasifikasi dan jenisnya tidak sama.

2. Penelitian relevan berikutnya ditulis oleh Elita Fitria Azhar, mahasiswa Universitas Indonesia. Berjudul "Nilai-Nilai Estetika pada Taman Jepang Khususnya pada Taman Karesansui". Dianalisis berdasarkan Teori Wabi dan Sabi menurut Terao Ichimu dan Teori Estetika Zen menurut Hisamatsu Shin'ichi. Penelitian ini dilakukakan pada tahun 2008. Tulisan ini relevan dengan penelitian yang dilakukan peneliti karena sama-sama menganalisis nilai estetika dalam buku. Perbedaannya adalah pada objek penelitiannya yakni peneliti sebelumnya pada novel sedangkan peneliti pada buku ungkapan adat Melayu, dan berangkat dari landasan teori ahli yang berbeda sehingga aspek nilai-nilai estetika yang dikaji pun klasifikasi dan jenisnya tidak sama.

3. Penelitian relevan berikutnya ditulis oleh Fitriani Ebi Pebriana, mahasiswa Universitas Maritim Raja Ali Haji Tanjung Pinang. Berjudul "Analisis Nilai Estetika dalam Gurindam
Mutiara Hidup karya Rendra Setyadiharja". Penelitian ini dilakukan pada tahun 2014. Tulisan ini relevan dengan penelitian yang dilakukan peneliti karena sama-sama menganalisis nilai estetika dalam buku. Perbedaannya adalah pada objek penelitiannya yakni peneliti sebelumnya pada novel sedangkan peneliti pada buku ungkapan adat Melayu, dan berangkat dari landasan teori ahli yang berbeda sehingga aspek nilai-nilai estetika yang dikaji pun klasifikasi dan jenisnya tidak sama.

\section{METODE PENELITIAN}

Penelitian ini menggunakan dua pendekatan yaitu pendekatan struktural dan stilistika. Pendekatan struktural dapat dikaji dengan cara melihat hubungan antara unsur yang saling berkaitan. Menurut Endraswara, (2013: 49). "Struktural adalah cara berpikir tentang dunia yang terutama berhubungan dengan tanggapan dan deskripsi strukturstruktur, dalam pandangan ini karya sastra diasumsikan sebagai fenomena yang memiliki struktur yang saling berkait satu sama lain". Sedangkan, pendekatan stilistika merupakan pendekatan yang menyangkut keindahan suatu karya sastra diantaranya bahasa yang mempunyai tugas dan peranan yang penting dalam kehadiran karya sastra."Stilistika adalah bidang studi tentang gaya bahasa (Style in Languange) tentu saja objeknya adalah bahasa bakunya" (Satoto, 2012: 31).

Metode yang digunakan dalam penelitian ini adalah deskriptif kualitatif. "Deskriptif adalah prosedur pemecahan masalah yang diselidiki dengan menggambarkan atau melukiskan 
keadaan subjek atau objek penelitian (puisi) berdasarkan fakta-fakta yang tampak atau sebagaimana adanya" Nawawi (dalam Siswantoro, (2010: 56)). Menurut Sugiyono (2016: 1) "Penelitian kualitatif adalah penelitian yang digunakan untuk meneliti pada kondisi objek yang alamia, di mana peneliti adalah sebagai instrumen kunci, teknik pengumpulan data dilakukan, penelitian kualitatif lebih menekankan makna daripada generalisasi”.

Teknik pengumpulan data dalam penelitian ini dilakukan dengan menggunakan langkah-langkah pendekatan struktural dan stilistika. Untuk lebih jelasnya dapat dilihat dalam penjelasan di bawah ini:

1. Langkah pertama, membaca keseluruhan buku sumber terlebih dahulu, kemudian menetapkan langkah dalam melakukan analisis stilistika ini adalah dari mana harus dimulai, apakah dari segi bunyi, kata frase, kalimat, paragraf, wacana, atau sebaliknya.

2. Langkah kedua, menganalisis masalah asonansi dalam ungkapan adat Melayu Riau karya Tenas Effendi serta, menandai setiap bagian dengan menggunakan stabilo yang menunjukkan nilai-nilai estetika.

3. Langkah ketiga, setelah data terkumpul, kemudian mengklasifikasi data sesuai dengan aspek nilai-nilai estetika yang terdapat terdapat dalam ungkapan adat Melayu, aspek yang telah di temukan kemudian dimasukkan ke dalam tabel tabulasi data.

Setelah data terkumpul di atas, selanjutnya dilakukan analisis data. Adapun tahapan yang dilakukan dalam analisis data adalah sebagai berikut:
1. Data yang telah terkumpul pada pengumpulan data di atas kemudian dimasukkan ke dalam tabel tabulasi data.

2. Menganalisis data yang ada pada tiap tabel tabulasi data dan disesuikan dengan teori (Kosasih 2008: 97) dan Keraf, (2016: 130). Berdasarkan pendapat Keraf peneliti hanya menganalisis keindahan pengulangan katanya saja.

3. Mendeskripsikan data yang telah dianalisis.

4. Merumuskan kesimpulan berdasarkan data yang telah dianalisis.

\section{HASIL DAN PEMBAHASAN}

Berdasarkan proses analis maka, ditemukan sebanyak 130 kutipan dari 25 ungkapan adat Melayu Riau karya Tenas Effendy pada buku Tegak Menjaga Tuah, Duduk Memelihara Marwah suntingan Makmur Hendrik dan kawan-kawan. Adapun 131 kutipan dari 25 ungkapan tersebut sebagai berikut:

1. Pada ungkapan adat Melayu Riau "Sifat tahu asal mula jadi, tahu berpegang pada yang satu" ditemukan nilai estetika gaya asonansi sebanyak 4 kutipan.

2. Pada ungkapan adat Melayu Riau "Sifat tahu membalas budi" ditemukan nilai estetika gaya bahasa asonansi sebanyak 4 kutipan.

3. Pada ungkapan adat Melayu Riau "Sifat hidup bertenggangan, mati berpegangan" ditemukan nilai estetika gaya bahasa asonansi sebanyak 2 kutipan.

4. Pada ungkapan adat Melayu Riau "Sifat tahu 'kan bodoh diri" ditemukan nilai estetika gaya bahasa asonansi sebanyak 6 kutipan.

5. Pada ungkapan adat Melayu Riau "Sifat tahu diri" ditemukan nilai 
estetika gaya bahasa asonansi sebanyak 4 kutipan.

6. Pada ungkapan adat Melayu Riau "Sifat hidup memegang amanah" ditemukan nilai estetika gaya bahasa asonansi sebanyak 3 kutipan.

7. Pada ungkapan adat Melayu Riau "Sifat benang orang" ditemukan nilai estetika gaya bahasa asonansi sebanyak 3 kutipan.

8. Pada ungkapan adat Melayu Riau "Sifat tahan menetang matahari" ditemukan nilai estetika gaya bahasa asonansi sebanyak 7 kutipan.

9. Pada ungkapan adat Melayu Riau "Sifat tahu menyimak pandai menyimpai" ditemukan nilai estetik gaya bahasa asonansi sebanyak 5 kutipan.

10. Pada ungkapan adat Melayu Riau "Sifat menang dalam kalah" ditemukan nilai estetika gaya bahasa asonansi sebanyak 14 kutipan.

11. Pada ungkapan adat Melayu Riau "Sifat tahan berkering mau berbasah" ditemukan nilai estetika gaya bahasa asonansi sebanyak 7 kutipan.

12. Pada ungkapan adat Melayu Riau "Sifat tahu unjuk dengan beri, tahu hidup bertenggangan" ditemukan nilai estetika gaya bahasa asonansi sebanyak 6 kutipan.

13. Pada ungkapan adat Melayu Riau "Sifat timbang dengan sikat" ditemukan nilai estetika gaya bahasa asonansi sebanyak 7 kutipan.

14. Pada ungkapan adat Melayu Riau "Sifat tahu "kan malu" ditemukan nilai estetika gaya bahasa asonansi sebanyak 2 kutipan.

15. Pada ungkapan adat Melayu Riau "Sifat berpada-pada" ditemukan gaya bahasa asonansi sebanyak 10 kutipan.

Penelitian ini membahas tentang nilai-nilai estetika gaya bahasa asonansi yang terdapat dalam ungkapan adat
Melayu Riau karya Tenas Effendy. Berdasarkan hasil penelitian yang telah dijabarkan di atas, dapat diperoleh data keseluruhan aspek nilai-nilai estetika gaya bahasa asonansi yaitu sebanyak 130 kutipan dari 25 ungkapan. Ada pun lebih jelasnya akan dideskripsikan pada bagian di bawah ini:

Nilai-nilai estetika gaya bahasa asonansi merupakan nilai keindahan menggunakan gaya bahasa dengan pengulangan vokal pada setiap bait ungkapan yaitu dengan mengulang bunyi vokal untuk menambah efek keindahan. Dalam ungkapan adat Melayu Riau karya Tenas Effendi terdapat sebanyak 131 kutipan dari 25 ungkapan, tetapi dalam artikel ini hanya 15 ungkapan yang disajikan, karena ke 15 ungkapan tersebut dianggap sudah mewakili data yang dimaksud, sebagai berikut:

1. Ungkapan adat Melayu Riau "Sifat tahu asal mula jadi, tahu berpegang pada yang satu" ditemukan gaya bahasa asonansi sebanyak 4 kutipan sebagai berikut:

\section{Tahu asal mula kejadian}

$\underline{\text { Tahu }}$ berpegang pada yang satu

Hamba tahu akan Tuhannya

Makhluk tahu akan Khaliknya

Pada kutipan yang bergaris bawah di atas, terdapat pengulangan vokal pada bait ke-1 larik 1-2 terdapat pengulangan vokal $a, u$, larik 3-4 terdapat pengulangan vokal $a, u, a$. Analisis ini sejalan dengan pendapat Tarigan (2009: 134) "Asonansi adalah sejenis gaya bahasa repetisi yang berwujud perulangan vokal yang sama untuk memperoleh efek keindahan". Diperkuat oleh pendapat Bella (2012) "Efek keindahan atau estetik merupakan hal utama yangada di dalam puisi karena puisi memadukan kekuatan bahasa, menyusunnya, merapikannya, kemudian diatur sedemikian rupa dengan memperlihatkan segi irama dan bunyi 
sehingga menghasilkan efek estetika tertentu". Efek-efek estetika ini lah yang membuat penikmat dapat memaknai sebagai puisi.

2. Pada ungkapan Adat Melayu Riau "Sifat tahu membalas budi" ditemukan gaya bahasa asonansi sebanyak 4 kutipan sebagai berikut:

$\underline{\text { Tahu }}$ 'kan perit ibu mengandung

$\underline{\text { Tahu }}$ 'kan pahit ayah mendukung

Tahu 'kan sakit membesarkannya

Tahu 'kan hutang yang dibebannya

Pada kutipan yang bergaris bawah di atas, terdapat pengulangan vokal vokal pada awal bait ke-1 larik 1-4 terdapat pengulangan vokal $a, u$.

3. Pada Ungkapan Adat Melayu Riau "Sifat hidup bertenggangan, mati berpegangan" ditemukan gaya bahasa asonansi sebanyak 2 kutipan sebagai berikut:

Yang hidup bertenggangan

Sama saudara berbaik-baikan

$\underline{\text { Sama sebangsa pelihara }}$

memeliharakan

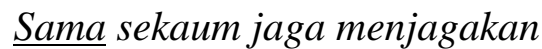

Sesama makhluk bertenggang-

tenggan

Pada kutipan yang bergaris bawah di atas, terdapat pengulangan vokal vokal pada awal bait ke-1 larik 2-4 terdapat pengulangan vokal $a$. Analisis ini sejalan dengan pendapat Tarigan (2009: 134) "Asonansi adalah sejenis gaya bahasa repetisi yang berwujud perulangan vokal yang sama untuk memperoleh efek keindahan. Diperkuat oleh pendapat Bella (2012) "Efek keindahan atau estetik merupakan hal utama yang ada di dalam puisi karena puisi memadukan kekuatan bahasa, menyusunnya, merapikannya, kemudian diatur sedemikian rupa dengan memperlihatkan segi irama dan bunyi sehingga menghasilkan efek estetika tertentu".
4.

ada ungkapan adat Melayu Riau "Sifat tahu "kan bodoh diri" ditemukan gaya bahasa asonansi sebanyak 6 kutipan sebagai berikut:

Tahu 'kankurang dari lebihnya

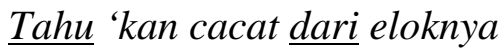

Tahu 'kan bodoh dari cerdiknya

$\underline{\text { Tahu 'kan bekal belum banyak }}$

Pada kutipan yang bergaris bawah di atas, terdapat pengulangan vokal pada awal bait ke-1 larik 1-4 terdapat pengulangan vokal $a, u$; ditengah bait ke1 larik 1-3 terdapat pengulanganvokal $a, i$;

5. Pada Ungkapan Adat Melayu Riau "Sifat tahu diri" ditemukan gaya bahasa asonansi sebanyak 4 kutipan sebagai berikut:

$\underline{\text { Tahu diridengan perihnya }}$

Tau hidup dengan matinya

Tahu marwah dengan tuahnya

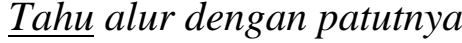

Pada kutipan yang bergaris bawah di atas, terdapat pengulangan vokal pada awal bait ke-1 larik 1-4 yaitu vokal $a, u$. Analisis ini sejalan pendapat Tarigan (2009: 134) "Asonansi adalah sejenis gaya bahasa repetisi yang berwujud perulangan vokal yang sama untuk memperoleh efek keindahan. Diperkuat oleh pendapat Bella (2012) "Efek keindahan atau estetik merupakan hal utama yang ada di dalam puisi karena puisi memadukan kekuatan bahasa, menyusunnya, merapikannya, kemudian diatur sedemikian rupa dengan memperlihatkan segi irama dan bunyi sehingga menghasilkan efek estetika tertentu". Efek-efek estetika ini lah yang membuat penikmat dapat memaknai sebagai puisi.

6. Pada ungkapan adat Melayu Riau "Sifat hidup memegang amanah" ditemukan gaya bahasa asonansi sebanyak 4 kutipan sebagai berikut: 
Yang disebut hidup memegang

amanah

Taat setia kepada agama

Taat setia kepada amanah

Taat setia kepada sumpah

Pada kutipan yang bergaris bawah di atas, terdapat pengulangan vokal pada setiap bait yang mengandung nilai keindahan. Dalam ungkapan tersebut terdapat pengulangan vokal pada awal bait ke-2-4 larik 2-4 yaitu vokal $a$;

7. Pada ungkapan adat Melayu Riau "Sifat benang orang" ditemukan gaya bahasa asonansi sebanyak 3 kutipan.

Lurus bagai benang arang

\section{Lurusnyamenahan bidik}

Pada kutipan yang bergaris bawah di atas, terdapat pengulangan vokal pada awal bait ke-1 larik 1-3 yaitu vokal $u$. Analisis ini sejalan dengan pendapat Tarigan (2009: 134) "Asonansi adalah sejenis gaya bahasa repetisi yang berwujud perulangan vokal yang sama untuk memperoleh efek keindahan. Diperkuat oleh pendapat Bella (2012) "Efek keindahan atau estetik merupakan hal utama yang ada di dalam puisi karena puisi memadukan kekuatan bahasa, menyusunnya, merapikannya, kemudian diatur sedemikian rupa dengan memperlihatkan segi irama dan bunyi sehingga menghasilkan efek estetika tertentu". Efek-efek estetika ini lah yang membuat penikmat dapat memaknai sebagai puisi.

8. Pada ungkapan adat Melayu Riau

"Sifat tahan menetang matahari" ditemuan gaya bahasa asonansi sebanyak 7 kutipan sebagai berikut:

Tahan menentang matahari

Tahan menepis mata pedang

Tahan menyilang mata keris

Pada kutipan yang bergaris bawah di atas, terdapat pengulangan vokal pada setiap bait yang mengandung nilai keindahan. Dalam ungkapan tersebut terdapat pengulangan vokal pada awal bait ke-1-3 larik 1-3 yaitu vokal $a$.

9. Pada ungkapan adat Melayu Riau "Sifat tahu menyimak pandai menyimpai" ditemukan gaya bahasa asonansi sebanyak 5 kutipan sebagai berikut:

\section{Arif menyimak kicau murai}

Arif menapis angin lalu

Arif mendengar desau daun

Arif menilik bintang di langit

Arif menangkap kerlingan orang

Pada kutipan yang bergaris bawah di atas, terdapat pengulangan vokal pada awal bait ke-1 larik 1-5 yaitu vokal $a, i$. Analisis ini sejalan dengan pendapat Tarigan (2009: 134) "Asonansi adalah sejenis gaya bahasa repetisi yang berwujud perulangan vokal yang sama untuk memperoleh efek keindahan". Diperkuat oleh pendapat Bella (2012) "Efek keindahan atau estetik merupakan hal utama yang ada di dalam puisi karena puisi memadukan kekuatan bahasa, menyusunnya, merapikannya, kemudian diatur sedemikian rupa dengan memperlihatkan segi irama dan bunyi sehingga menghasilkan efek estetika tertentu". Efek-efek estetika ini lah yang membuat penikmat dapat memaknai sebagai puisi.

10. Pada ungkapan adat Melayu Riau "Sifat menang dalam kalah" ditemukan gaya bahasa asonansi sebanyak 14 kutipan sebagai berikut:

Lapang dada luas hati

Lapangnyatidak berhempang

Luasnya tidak berbatas

Dalamnya tidak terukur

Kayanya tidak tertukar

Beratnya tidak tertimbang

Cerdik menjadi penyambung lidah

Berani menjadi pelapis dada

Kuatnya menjadi tiang sendi

Pada kutipan yang bergaris bawah di atas, terdapat pengulangan vokal awal 
bait ke-2 larik 1-2 yaitu vokal $a$; ditengah larik 2-6 terdapat pengulangan vokal $a, i$. 11. Pada ungkapan adat Melayu Riau "Sifat tahan berkering mau berbasah" ditemukan gaya bahasa asonansi sebanyak 7 kutipan sebagai berikut:

\section{Tahan berkering mau berbasah}

$\underline{\text { Tahan digilas mau digiling }}$

Pada kutipan yang bergaris bawah di atas, terdapat pengulangan vokal pada awal bait ke-1 larik 1-2 yaitu vokal a,a. Analisis ini sejalan dengan pendapat Tarigan (2009: 134) "Asonansi adalah sejenis gaya bahasa repetisi yang berwujud perulangan vokal yang sama untuk memperoleh efek keindahan". Diperkuat oleh pendapat Bella (2012) "Efek keindahan atau estetik merupakan hal utama yang ada di dalam puisi karena puisi memadukan kekuatan bahasa, menyusunnya, merapikannya, kemudian diatur sedemikian rupa dengan memperlihatkan segi irama dan bunyi sehingga menghasilkan efek estetika tertentu".Efek-efek estetika ini lah yang membuat penikmat dapat memaknai sebagai puisi.

12. Pada Ungkapan Adat Melayu Riau "Sifat tahu unjuk dengan beri, tahu hidup bertenggangan" ditemukan gaya bahasa asonansi sebanyak 6 kutipan sebagai berikut:

Tahu unjuk dengan beri

Tahu menjalin gelegar patah

Tahu menjirat lantai terjungkal

Tahu menampal liang dinding

Tahu menenggang hati orang

Tahu menimbang perasaan orang

Tahu menjaga aib malu orang

Tahu menutupi kekurangan orang

Pada kutipan yang bergaris bawah di atas, terdapat pengulangan vokal pada awal bait ke-1 larik 1-2 yaitu vokal $a, a$, diakhir larik 1-2 terdapat pengulangan vokal $a, u$.
13. Pada ungkapan adat Melayu Riau "Sifat timbang dengan sikat" ditemukan gaya bahasa asonansi sebanyak 7 kutipan sebagai berikut:

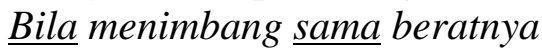

Bila menyukat sama penuhnya

Bila membelah sama baginya

Bila mengukur sama panjangnya

Pada kutipan yang bergaris bawah di atas, terdapat pengulangan vokal pada awal bait ke-1 larik 1-4 terdapat pengulangan vokal $i, a$, ditengah larik 14 terdapat pengulangan vokal $a$, diakhir larik terdapat pengulangan vokal $a$. Analisis ini sejalan dengan pendapat Tarigan (2009: 134) "Asonansi adalah sejenis gaya bahasa repetisi yang berwujud perulangan vokal yang sama untuk memperoleh efek keindahan".Diperkuat oleh pendapat Bella (2012) "Efek keindahan atau estetik merupakan hal utama yang ada di dalam puisi karena puisi memadukan kekuatan bahasa, menyusunnya, merapikannya, kemudian diatur sedemikian rupa dengan memperlihatkan segi irama dan bunyi sehingga menghasilkan efek estetika tertentu". Efek-efek estetika ini lah yang membuat penikmat dapat memaknai sebagai puisi.

14. Pada ungkapan adat Melayu Riau "Sifat tahu "kan malu" ditemukan gaya bahasa asonansi sebanyak 2 kutipan sebagai berikut:

Yang disebut sifat malu

Malu membuka aib orang

Malu menyikap baju dibadan

Malu mencoreng arang dikening

Malu melanggarpada syarak

Malu terlanda pada adat

Malu tertarung pada lembanga

Malu merusak nama baik

Malu memutus tali darah

Malu hidup menanggung malu

Malu mati tidak bermalu 
Pada kutipan yang bergaris bawah di atas, terdapat pengulangan vokal pada awal bait ke-1 larik 2-11 yaitu vokal $a, u$, ditengah larik 5-7 terdapat pengulangan vokal kata $a$.

15. Pada ungkapan adat Melayu Riau

"Sifat berpada-pada" ditemukan gaya bahasa asonansi sebanyak 10 kutipan sebagai berikut:

\section{Yang disebut sifat berpada-pada}

Mengejar pangkat berkira-kira

Mengejar harta berhingga-hingga

Mengejar kedudukan berjaga-jaga

Pada kutipan yang bergaris bawah di atas, terdapat pengulangan vokal pada bait ke-1 larik 2-4 terdapat pengulangan vokal a. Analisis ini sejalan dengan

\section{KESIMPULAN}

Berdasarkan hasil penelitian dan pembahasan, maka dapat disimpulkan bahwa pada buku Tegak Menjaga Tuah, Duduk Memelihara Marwah suntingan Makmur Hendrik dan kawan-kawan. Terdapat 130 kutipan yang mengandung nilai-nilai estetika berupa gaya bahasa asonansi.

Berdasarkan kesimpulan di atas, dapat diketahui bahwa nilai estetika berupa gaya bahasa asonansi yang paling dominan yang terdapat dalam ungkapan adat Melayu Riau "Sifat yang pucuk" sebanyak 19 kutipan dan yang paling sedikit di temukan sebanyak 1 kutipan yaitu, pada ungkapan adat Melayu Riau "Sifat berbaik sangka".

\section{REKOMENDASI}

Berdasarkan kesimpulan di atas, maka peneliti dapat menyampaikan beberapa rekomendasi sebagai berikut:

1. Kepada para pembaca agar dapat mengaplikasikan temuan-temuan nilai estetika pada penelitian ini dalam karya sastra lainnya, sehingga dapat tercipta karya sastra yang pendapat Tarigan (2009: 134) "Asonansi adalah sejenis gaya bahasa repetisi yang berwujud perulangan vokal yang sama untuk memperoleh efek keindahan. Diperkuat oleh pendapat Bella (2012) "Efek keindahan atau estetik merupakan hal utama yang ada di dalam puisi karena puisi memadukan kekuatan bahasa, menyusunnya, merapikannya, kemudian diatur sedemikian rupa dengan memperlihatkan segi irama dan bunyi sehingga menghasilkan efek estetika tertentu". Efek-efek estetika ini lah yang membuat penikmat dapat memaknai sebagai puisi.

indah dan dapat dinikmati oleh banyak orang.

2. Kepada peneliti lain agar dapat melakukan penelitian atau kajian lebih mendalam karena peneliti meyakini bahwa dalam ungkapan adat Melayu Riau ini masih terdapat aspek-aspel dan nilai-nilai lain yang potensi untuk diteliti atau sebagai bahan kajian.

\section{DAFTAR PUSTAKA}

Bella Nurlisa Revyna. (2012). Estetika yang Terkandung dalam Puisi Arisihi Hi NoUta Karya Nakahara Chuuya (Melalui Pendekatan Ekspersip). http://portalgaruda.org.

Damayanti, D. (2013). Buku Pintar Sastra Indonesia. Yogyakarta: Araska.

Endraswara, Suwardi. (2013). Metode Peneliti Sastra, Epitemologi, Model, Teori, dan Aplikasi. Yogyakarta: CAPS (Center for Academic Publising Service). 
Hendrik, Makmur, dkk. (2005). Tegak Menjaga Tuah, Duduk Memelihara Marwah. Balai Kajian dan Perkembangan Budaya Melayu. Yogyakarta: Mitra Gama Widya.

Keraf, Gorys. (2009). Diksi dan Gaya Bahasa. Jakarta: Gramedia Pustaka Utama.

Kosasih, E. (2008). Dasar-Dasar Keterampilan Bersastra.Bandung: Yrama Widya.

Satoto, Soediro. (2012). Stilistika. Perpustakaan Nasional: Katalog DalamTerbitan (KDT).

Yogyakarta: Ombak.

Siswantoro, (2010). Metode Penelitian Sastra, Analisis Struktural Puisi. Yogyakarta: Pustaka Pelajaran.
Tarigan, Henry, Guntur. 2008. Membaca Sebagai Suatu Keterampilan Berbahasa. Bandung: Angkasa

Teeuw, A. (2013). Sastra dan Ilmu Sastra.Bandung: PT Dunia Pustaka Jaya.University Press.

Waluyo, Herman. 1991. Teori dan Apresasi Puisi. Bandung: Angkasa.

Wardoyo.Sigit.Magun. 2013. Teknik Penulisan Puisi. Pemahaman Menulis Puisi untuk Siswa, Mahasiswa, Guru dan Dosen. Yogyakarta: Graha Ilmu.

Wellek Rene dan Warren Austin. (2016). Teori Kesusastraan. Jakarta: PT Gramedia Pustaka Utama. 